\title{
FINANCIAL LITERACY AMONG STUDENTS \\ OF NILKANTHA MULTIPLE CAMPUS
}

Rupakheti, Ram Chandra ${ }^{9^{*}}$

\section{Abstract}

The purpose of this research is to assess the level of financial literacy and its impact on college students in Nepal. This study surveys 60 students from Nilakantha Multiple Campus out of 896 students. This research used a structured questionnaire complemented by multiple choices to select the correct answer. The students taken for the study were from BBS group. Each 60 students have filled the questionnaire. The research reveals that financial literacy among students appears to be below the average level. It can be concluded that students have poor financial planning. Students have not enough knowledge about the importance of savings. Budgeting and financial plan of students have been found below average level. The overall students' performance in the questions found 49.84\% which is below the benchmark of Chen, Volpe, and Pavlicko. Overall, the study reveals that students were not as financially literate as expected. It is, therefore, recommended that a comprehensive and aggressive program of financial education be carried out especially among young people in Nepal by policy makers.

\section{Keywords:}

Cridet, Financial Literacy, Savings,

\section{Introduction}

The concept of financial literacy is the ability to understand how money works in the world: how someone manages to earn or make it, how that person manages it, how he/she invests it and how that person donates it to help others. More specifically, it refers to the set of skills and knowledge that allows an individual to make informed and effective decisions with all of their financial resources (Wikipedia). Financial literacy is a path to sustainability and has an important role in ensuring the financial sustainability of individuals, families, enterprises and national economies (Swiecka, Yesilda, Ozen, \& Simon, 2020). It is a combination of awareness, knowledge, skill, attitude and behavior necessary to make sound financial decisions and ultimately achieve individual financial wellbeing (NRB, 2020). In other words, it consists of economic activities related with

$9{ }^{*}$ Mr. Rupakheti is Lecturer, Nilkantha Multiple Campus Dhading, Nepal can be corresponded at

expertrcr@gmail.com 
earning, saving, investing and effective utilization by human beings. Family income affects the level of financial literacy of students with the amount of income being inversely proportional to the financial knowledge (Ilias \& Helen, 2019; Badal, 2019). Financial literacy is a combination of awareness, knowledge, skill, attitude and behavior necessary to make sound financial decisions and ultimately achieve individual financial well-being (OECD, 2017, p. 13).

Increasing financial literacy and capability promotes better financial decision-making, thus, enabling better planning and management of life events such as education, housing purchase, or retirement. This is particularly more relevant for college students (Mahdzan \& Tabiani, 2013). Financial literacy such as health or general literacy might be conceptualized with two main dimensions: understanding personal finance knowledge and using it. Hence, it could be described as measuring how well an individual can understand and use personal finance-related information (Huston, 2010, p.306).

\section{Statement of the Problem}

Swamy, M.B. \& Priya R (2017) concluded that financial literacy was highest among business students. Further, they revealed that formal education is the main source of financial literacy of postgraduate students, followed by parents, the media, and peers. Servon and Kaestner (2008, p.273) defines financial literacy as a person's ability to understand and make use of financial concepts. The problem is that teachers, administrators, parents, business owners, and community members need to know if a personal finance level is valuable enough to enhance for economic development in Nepal. Further, there should be added program to improve financial literacy program from college level to society in Nepal or not. This research is an important to identify the gap therein. This study, therefore, seeks to research into the level of financial literacy among college students in Nepal.

\section{Objectives of the study}

The specific objectives of the study are as follows:

i. To find out the general financial knowledge on savings and credit.

ii. To find the impact of financial knowledge on their opinions

iii. To examine the impact of financial knowledge on their personal financial decision.

\section{Review of literature}

Walt, F., \& Fouche., Jaco (2017) conducted study with the objective to determine undergraduate students' financial literacy at a public university. The participants' knowledge regarding the issues 
relating to general financial literacy was observed to be low. They also performed poorly in terms of banking and taxation and financial planning, interest rates and general inflation. It was also reported that there is a significant difference between many groups within the biographical data. Abdullah et al. (2017) indicated family influence has the highest significant effect on financial literacy compared to the personality characteristics (financial attitude and financial behavior) and financial knowledge.

Ilias \& Helen (2019) have conducted a survey on "Financial Literacy of Graduate High School Students" intending to measure the level of financial literacy of high school students in all questions and each basic field of financial knowledge. The basic fields of financial knowledge are 1) Income, 2) Programming and Money Management, 3) Credit and Debit, and 4) Savings and Investments. The survey concluded that the level of financial literacy of high school students was low in comparison with the corresponding high school students in other countries from similar surveys conducted.

Thapa \& Nepal (2015) have researched "Financial Literacy in Nepal: A Survey Analysis from College Students" to examine their financial literacy; the impact of demographic, educational, and personality characteristics on financial literacy. Results show that most of the students have an average level of financial knowledge but they lack understanding of credit, financial statement, insurance, share market, and taxes.

The influence of parents' attitudes on students towards savings changes saving habits positively. Further, the research identified income, age, a stream of education, types of college, and attitude of students as determinants of financial knowledge; and financial knowledge is unaffected by gender, university affiliation, financial behavior, and influence. It is concluded that college students have a basic level of financial knowledge. However, the overall financial knowledge of the students is affected by some of their demographic, educational, and personality characteristics.

Sarigul \& Hasmet (2014) has researched on "A Survey of Financial Literacy Among University Students" with the objectives to determine the level of financial literacy among university students, to find out the relationship between financial literacy and student characteristics, and to provide an information resource that may assist with the development. In this study, a survey instrument that includes 29 items such as saving and spending, banking, risk and insurance, investing, and general financial knowledge levels of the participants. He argued that the percentages of correct answers from the students' who live in private households were lower than the others for the general knowledge section and the entire survey. Further, it is concluded that students' parent's education positively influenced on student's financial knowledge.

Chen \& Volpe (1998) conducted a survey of 924 US college students to examine their personal 
financial literacy, the relationship between the literacy and students' characteristics, and impact of the literacy on students' opinions and decisions. They used a comprehensive questionnaire designed to cover major aspects of personal financial literacy on general knowledge, savings and borrowing, insurance, and investments. The results show that respondents answered about 53 per cent of questions correctly. The study found also that women pursuing non-business careers and with little work experience have lower levels of financial literacy. Those students who are less knowledgeable were found to hold wrong views about personal finance and this low level of knowledge limits their ability to make informed financial decisions.

\section{Methodology}

Sampling and Methodology

The study area is in the context of the Nilkantha Municipalities of Dhading, which is an urban area. A descriptive research method has been applied to analyze and interpret the quantitative and qualitative data. A judgmental sampling method is followed where 60 students were selected from total campus students of 896. The selected students were from business students expecting they have good financial knowledge than other non-business students. This study is mainly based on primary data collected from field surveys by using a structured questionnaire where each individual selected in the sample have been given questions separately. They filled up given questionnaire based on their knowledge. The data are of discrete nature collected from 15 male students and 45 female students. The questions were short and specific in a structured questionnaire therein in which replies were filled by all 60 students. A questionnaire captured relevant information on major aspects of financial literacy. This study adopts the simple random sampling technique to collect the relevant primary data. There was no fault in data collection because each questionnaire was filled up by students based on their knowledge in front of the researcher. The questions and choices are discussed to clear the meaning of each word. The terms used in the research questions are very short, simple, and easy to understand. The total time taken to fill up all questions is 40 minutes. The responses from each respondent were used to calculate the mean percentage of correct scores for each question, section, and the entire survey. So, the data collected is the most reliable and authenticated.

\section{Study Site}

The Nilakantha Multiple Campus is located at Nilkantha Munucipality, Dhadingbesi, Dhading district in Nepal. It is an urban area, city of Dhading district. The municipality is located 90 kilometers west from Kathmandu and it is $18 \mathrm{~km}$ from Malekhu, a point in Prithvi highway. It is the business hub of Dhading district. There are 21 branches of banks and financial institutions. There are 15 branches of microfinance and six insurance companies. There is good financial access in this area. 
It is very important to find out the level of financial literacy and awareness from business students.

\section{Data analysis and interpretation}

The researcher sought to answer three key questions on the financial literacy of students in the Nilkantha Multiple Campus. Specifically, the study is to investigate; (1) the general knowledge of BBS students in terms of financial management, (2) the extent to which the students appreciate issues concerning savings and borrowing, (3) their exposure to financial issues. This section provides evidence on the descriptive statistics on the respondents of the survey in terms of educational and demographic characteristics and exposure to financial issues. The main purpose of descriptive statistics is to provide a summary of the samples and the measures done on a particular study. In this research, table and its description has been made extensively.

\section{Demographic characteristics}

On their demographic characteristics, the results show that most of the students in the survey are female students representing about $75 \%$ of the sample size with the remaining $25 \%$ being male students. In examining the respective ages of the students in the survey, the results reveal that $45 \%$ of the students are 20 years and below whilst 55\% are between the ages of 21 to 25 years. Based on the students' ages, it can be inferred that the students are in their youthful age and hence there is the tendency to be influenced by their peers in their decision making. The age groups are cable enough for taking financial decision.

\section{Demographic Characteristics}

\begin{tabular}{|l|c|r|}
\hline \multicolumn{1}{|c|}{ Age Group } & Number of students & Percentage \\
\hline UPTO 20 & 27 & $45.00 \%$ \\
\hline $20-25$ & 33 & $55.00 \%$ \\
\hline \multicolumn{3}{|c|}{ Gender } \\
\hline Male & 15 & $25.00 \%$ \\
\hline Female & 45 & $75.00 \%$ \\
\hline
\end{tabular}

(Study, 2020) 


\section{Exposure to financial issues}

\section{Living in Capital Town of Dhading District}

\begin{tabular}{|c|c|c|c|c|}
\hline \multicolumn{5}{|c|}{ Living in Capital Town of Dhading District } \\
\hline Response & Male & Female & Male Percent & Female \\
\hline Yes & 13 & 34 & $86.67 \%$ & $75.56 \%$ \\
\hline No & 2 & 11 & $13.33 \%$ & $2.00 \%$ \\
\hline
\end{tabular}

(Study, 2020)

On the exposure to financial issues, the results show that $78.33 \%$ of the students lived in the capital town whilst $21.67 \%$ of the students were not. The majority of the students are female living in the capital town of Dhading district.

\section{Father's Education}

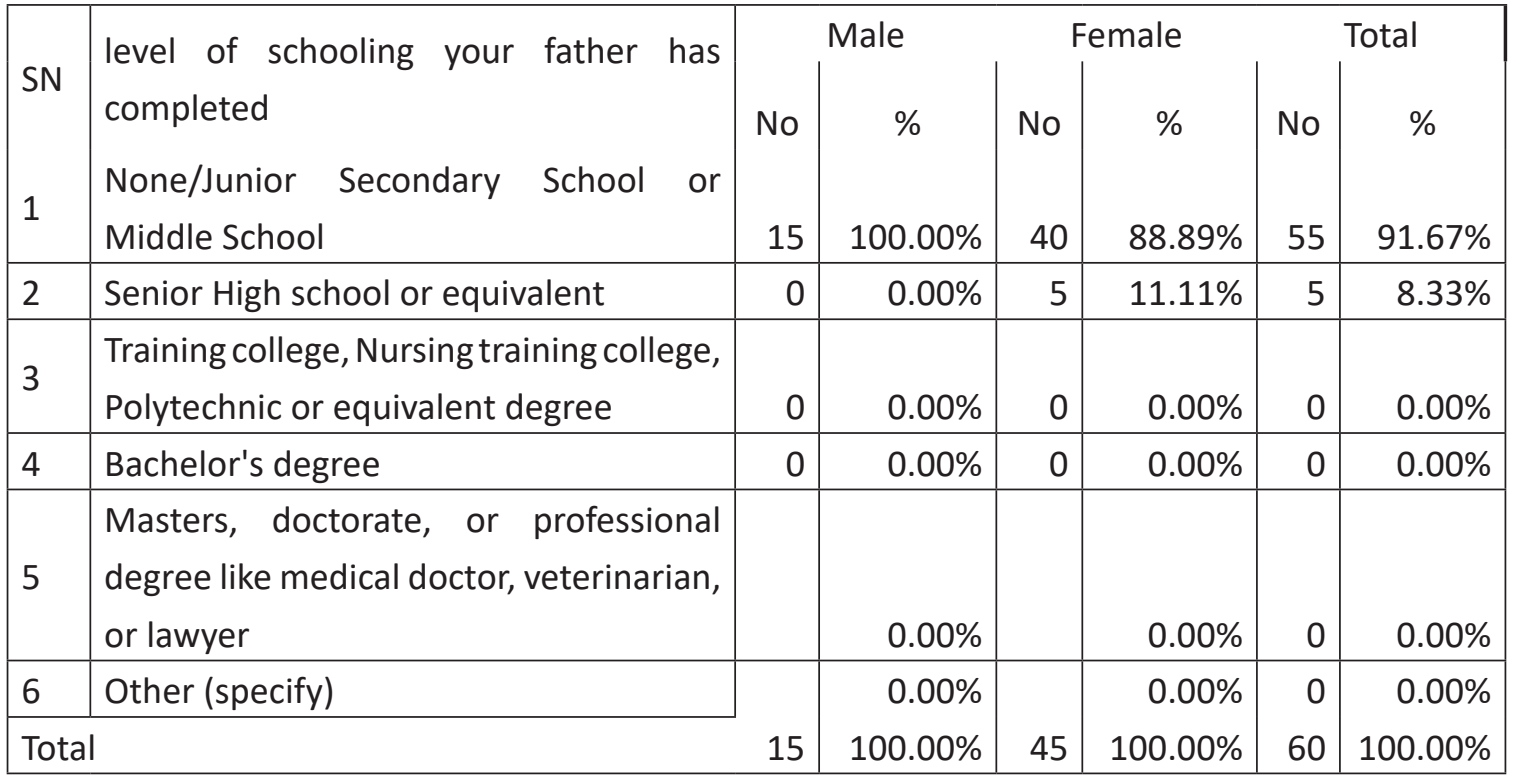

(Study, 2020)

Notwithstanding, the results show that on fathers' education, $91.67 \%$ either have no formal education or have been educated up to JHS/Middle School education level whilst $8.33 \%$ have up to higher studies. 


\section{Mother's Education}

\begin{tabular}{|c|c|c|c|c|c|c|c|}
\hline \multirow{2}{*}{ SN } & \multirow{2}{*}{$\begin{array}{l}\text { level of schooling your mother has } \\
\text { completed }\end{array}$} & \multicolumn{2}{|r|}{ Male } & \multicolumn{2}{|c|}{ Female } & \multicolumn{2}{|c|}{ Total } \\
\hline & & No & $\%$ & No & $\%$ & No & $\%$ \\
\hline 1 & $\begin{array}{l}\text { None/Junior Secondary School or Middle } \\
\text { School }\end{array}$ & 14 & $93.33 \%$ & 42 & $93.33 \%$ & 56 & $93.33 \%$ \\
\hline 2 & Senior High school or equivalent & 1 & $6.67 \%$ & 3 & $6.67 \%$ & 4 & $6.67 \%$ \\
\hline 3 & $\begin{array}{l}\text { Training college, Nursing training college, } \\
\text { Polytechnic or equivalent degree }\end{array}$ & 0 & $0.00 \%$ & 0 & $0.00 \%$ & 0 & $0.00 \%$ \\
\hline 4 & Bachelor's degree & 0 & $0.00 \%$ & 0 & $0.00 \%$ & 0 & $0.00 \%$ \\
\hline 5 & $\begin{array}{l}\text { Masters, doctorate, or professional } \\
\text { degree like medical doctor, veterinarian, } \\
\text { or lawyer }\end{array}$ & 0 & $0.00 \%$ & 0 & $0.00 \%$ & 0 & $0.00 \%$ \\
\hline 6 & Other (specify) & 0 & $0.00 \%$ & 0 & $0.00 \%$ & 0 & $0.00 \%$ \\
\hline \multicolumn{2}{|c|}{ Total } & 15 & $100.00 \%$ & 45 & $100.00 \%$ & 60 & $100.00 \%$ \\
\hline
\end{tabular}

(Study, 2020)

The results show that on mothers' education, $93.33 \%$ either have no formal education or have been educated up to JHS/Middle School education level whilst $6.67 \%$ have up to higher studies.

\section{Percentage Response of Participants' Knowledge in Financial Literacy}

\section{Personal finance literacy}

\section{Personal finance literacy}

\begin{tabular}{|l|l|l|l|l|l|l|l|}
\hline \multirow{2}{*}{ Gender } & \multicolumn{3}{l}{ Correct } & \multicolumn{3}{l|}{ Incorrect } & \multicolumn{2}{l|}{ Don't know } \\
& No & Percentage & No & Percentage & No & Percentage \\
\hline Male & 6 & $40.00 \%$ & 8 & $53.33 \%$ & 1 & $6.67 \%$ \\
\hline Female & 14 & $31.11 \%$ & 30 & $66.67 \%$ & 1 & $2.22 \%$ \\
\hline Total & 20 & $33.33 \%$ & 38 & $63.33 \%$ & 2 & $3.33 \%$ \\
\hline
\end{tabular}

(Study, 2020)

The findings from the table show that $33.33 \%$ is correct whilst $63.33 \%$ is incorrect on the question regarding personal financial literacy. Out of correct responses, males are $40 \%$ out of total male respondents whereas females are $31.11 \%$ out of total female respondents. In the above result, 
male students have good personal financial literacy.

Personal financial planning

\begin{tabular}{|c|c|c|c|c|c|c|}
\hline \multirow{2}{*}{ Gender } & \multicolumn{2}{|c|}{ Correct } & \multicolumn{2}{|c|}{ Incorrect } & \multicolumn{2}{|c|}{ Don't know } \\
\hline & No & Percentage & No & Percentage & No & Percentage \\
\hline Male & 2 & $13.33 \%$ & 13 & $86.67 \%$ & 0 & $0.00 \%$ \\
\hline Female & 2 & $4.44 \%$ & 43 & $95.56 \%$ & 0 & $0.00 \%$ \\
\hline Total & 4 & $6.67 \%$ & 56 & $93.33 \%$ & 0 & $0.00 \%$ \\
\hline
\end{tabular}

(Study, 2020)

Observing personal financial planning, 13.33 percent gave correct answers whilst 86.67 percent gave the wrong answer. The majority of them were female students.

\section{A personal budget}

\section{Personal budget}

\begin{tabular}{|l|l|l|l|l|l|l|}
\hline \multirow{2}{*}{ Gender } & \multicolumn{3}{l}{ Correct } & \multicolumn{3}{c|}{ Incorrect } \\
& No & Percentage & No & Percentage & No & Percentage \\
\hline Male & 3 & $20.00 \%$ & 12 & $80.00 \%$ & 0 & $0.00 \%$ \\
\hline Female & 13 & $28.89 \%$ & 31 & $68.89 \%$ & 1 & $2.22 \%$ \\
\hline Total & 16 & $26.67 \%$ & 43 & $71.67 \%$ & 1 & $1.67 \%$ \\
\hline
\end{tabular}

It shows that 71.67 percent of total student didn't know how personal budget helps them. Only 26.67 percent of the total respondents gave the correct answer.

\section{Asset Liquidity}

\section{Assets Liquidity}

\begin{tabular}{|l|r|r|r|r|r|r|}
\hline \multirow{2}{*}{ Gender } & \multicolumn{1}{l}{ Correct } & \multicolumn{2}{l}{ Incorrect } & \multicolumn{2}{l|}{ Don't know } \\
\cline { 2 - 7 } & No & Percentage & No & Percentage & No & Percentage \\
\hline Male & 13 & $86.67 \%$ & 1 & $6.67 \%$ & 1 & $6.67 \%$ \\
\hline Female & 36 & $80.00 \%$ & 8 & $17.78 \%$ & 1 & $2.22 \%$ \\
\hline Total & 49 & $81.67 \%$ & 9 & $15.00 \%$ & 2 & $3.33 \%$ \\
\hline
\end{tabular}

(Study, 2020)

This shows that students have good knowledge of liquid assets. 81.67 percent of the total students give the correct answer. 
Savings interest

Saving Interest

\begin{tabular}{|c|c|c|c|c|c|c|}
\hline \multirow{2}{*}{ Gender } & \multicolumn{2}{|c|}{ Correct } & \multicolumn{2}{|c|}{ Incorrect } & \multicolumn{2}{|c|}{ Don't know } \\
\hline & No & Percentage & No & Percentage & No & Percentage \\
\hline Male & 11 & $73.33 \%$ & 4 & $26.67 \%$ & 0 & $0.00 \%$ \\
\hline Female & 16 & $35.56 \%$ & 23 & $51.11 \%$ & 6 & $13.33 \%$ \\
\hline Total & 27 & $45.00 \%$ & 27 & $45.00 \%$ & 6 & $10.00 \%$ \\
\hline
\end{tabular}

(Study, 2020)

They have not had satisfactory knowledge about the interest rate. Only 45 percent of the students give the correct answer. 45 percent of the students gives incorrect response. Remaining 10 percent of the students don't have any knowledge about the impact of the interest rate. The mean of the correct answer is $38.67 \%$ out of the total students from general financial knowledge. This shows very poor results regarding the financial literacy level of BBS students. Therefore, the general financial literacy level of students from the commerce group is very poor.

\section{Saving and Borrowing Knowledge}

Most Interest Paid Account

Most Interest Paid Account

\begin{tabular}{|l|l|r|r|r|r|r|}
\hline \multirow{2}{*}{ Gender } & \multicolumn{6}{|l|}{ Correct } \\
& No & Percentage & No & Percentage & No & percentage \\
\hline Male & 10 & $66.67 \%$ & 5 & $33.33 \%$ & 0 & $0.00 \%$ \\
\hline Female & 31 & $68.89 \%$ & 13 & $28.89 \%$ & 1 & $2.22 \%$ \\
\hline Total & 41 & $68.33 \%$ & 18 & $30.00 \%$ & 1 & $1.67 \%$ \\
\hline
\end{tabular}

(Study, 2020)

In the above $68.33 \%$, respondents give correct answers whilst $30 \%$ give an incorrect answer. $1.67 \%$ of the total students don't know about the answer. 


\section{Guarantee of Loan}

\section{Guarantee of Loan}

\begin{tabular}{|l|l|r|r|r|r|r|}
\hline \multirow{2}{*}{ Gender } & \multicolumn{2}{|l|}{ Correct } & \multicolumn{3}{|l|}{ Incorrect } & \multicolumn{2}{l|}{ Don't know } \\
& No & Percentage & No & Percentage & No & percentage \\
\hline Male & 11 & $73.33 \%$ & 4 & $26.67 \%$ & 0 & $0.00 \%$ \\
\hline Female & 31 & $68.89 \%$ & 12 & $26.67 \%$ & 2 & $4.44 \%$ \\
\hline Total & 42 & $70.00 \%$ & 16 & $26.67 \%$ & 2 & $3.33 \%$ \\
\hline
\end{tabular}

(Study, 2020)

In the above $70 \%$, respondents give correct answers whilst $26.67 \%$ give an incorrect answer.

$3.33 \%$ of the total students don't know about the answer.

Higher Interest Rate

\section{Higher Interest Rate}

\begin{tabular}{|l|r|r|r|r|r|r|}
\hline \multirow{2}{*}{ Gender } & \multicolumn{6}{|l}{ Correct } \\
& No & Percentage & No & percentage & No & percentage \\
\hline Male & 9 & $60.00 \%$ & 6 & $40.00 \%$ & 0 & $0.00 \%$ \\
\hline Female & 18 & $40.00 \%$ & 26 & $57.78 \%$ & 1 & $2.22 \%$ \\
\hline Total & 27 & $45.00 \%$ & 32 & $53.33 \%$ & 1 & $1.67 \%$ \\
\hline
\end{tabular}

(Study, 2020)

In the above $45.00 \%$, respondents give correct answers whilst $53.33 \%$ give an incorrect answer.

$1.67 \%$ of the total students don't know about the answer.

\section{An Overdraft Accounts}

\section{An Overdraft Account}

\begin{tabular}{|l|l|l|l|l|l|l|}
\hline \multirow{2}{*}{ Gender } & \multicolumn{3}{l}{ Correct } & \multicolumn{2}{l|}{ Incorrect } & \multicolumn{2}{l|}{ Don't know } \\
& No & Percentage & No & percentage & No & percentage \\
\hline Male & 12 & $80.00 \%$ & 3 & $20.00 \%$ & 0 & $0.00 \%$ \\
\hline Female & 29 & $64.44 \%$ & 9 & $20.00 \%$ & 7 & $15.56 \%$ \\
\hline Total & 41 & $68.33 \%$ & 12 & $20.00 \%$ & 7 & $11.67 \%$ \\
\hline
\end{tabular}

(Study, 2020) 
In the above table, $68.33 \%$ of respondents give correct answers whilst $20.00 \%$ give an incorrect answer. $11.67 \%$ of the total students don't know about the answer.

\section{Credit Criteria}

\section{Credit Criteria}

\begin{tabular}{|l|l|l|l|l|l|l|}
\hline \multirow{2}{*}{ Gender } & \multicolumn{6}{l}{ Correct } \\
& No & Percentage & No & Percentage & No & Percentage \\
\hline Male & 0 & $0.00 \%$ & 15 & $100.00 \%$ & 0 & $0.00 \%$ \\
\hline Female & 32 & $71.11 \%$ & 13 & $28.89 \%$ & 0 & $0.00 \%$ \\
\hline Total & 32 & $53.33 \%$ & 28 & $46.67 \%$ & 0 & $0.00 \%$ \\
\hline
\end{tabular}

(Study, 2020)

In the above $53.33 \%$ respondents give correct answer whilst $46.67 .00 \%$ give incorrect answer. The mean of correct answer is $61 \%$ out of total students from Saving and Borrowing section. This shows satisfactory result regarding the financial literacy level of BBS students. Therefore, saving and borrowing level of students from commerce group is satisfactory.

\section{Overall mean $(\mathrm{I}+\mathrm{II})=\mathbf{4 9 . 8 4 \%}$}

The initial aspect looks at the scores that are correct, incorrect, and don't know. The second aspect emphasizes the respective questions asked under each of the financial literacy components namely; general financial knowledge and savings and borrowing. This is to ascertain the understanding of the students of the financial literacy components. In comparison to Chen and Volpe (1998) benchmark of financial literacy, the percentage correct scores are regrouped into three categories: over $80 \%$ (Highest), $60-79 \%$ (Medium) and below 60\% (Low) to make an informed decision on the student's level of financial literacy. In this survey, the overall mean from both section: general financial section and borrowing section is $49.84 \%$ which is a very low level of financial literacy. it is not enough to cushion their understanding of money management issues in our current financial world.

\section{The Impact of Students' Financial Knowledge on Their Opinions.}

The researcher further tries to ascertain how student's financial knowledge influences their opinions. The financial knowledge as per students' personal financial opinion categorized into two parts male and female. 


\section{Students maintaining adequate financial records}

Maintaining adequate financial records

\begin{tabular}{|l|l|l|l|l|l|}
\hline Gender & A-Very unimportant & B-Unimportant & C-Not sure & D-Important & E-Very important \\
\hline Male & $6.67 \%$ & $0.00 \%$ & $13.33 \%$ & $33.33 \%$ & $46.67 \%$ \\
\hline Female & $4.44 \%$ & $0.00 \%$ & $15.56 \%$ & $31.11 \%$ & $48.89 \%$ \\
\hline Total & $5.00 \%$ & $0.00 \%$ & $15.00 \%$ & $31.67 \%$ & $48.33 \%$ \\
\hline
\end{tabular}

(Study, 2020)

On the above table, it is found that $5 \%$ of the total students feel it is not important to maintain adequate financial records whilst $15 \%$ feel that it is not sure to maintain the financial records. 80 $\%$ of the students feel it is important to financial records. In comparison to males, both male and female respondents equally feel it is important to financial records. They are both $80 \%$ of each group of male and female respondents.

\section{Students spending less than their income}

\section{Spending less than your income}

\begin{tabular}{|l|l|l|l|l|l|}
\hline Gender & A-Very unimportant & B-Unimportant & C-Not sure & D-Important & E-Very important \\
\hline Male & $13.33 \%$ & $20.00 \%$ & $0.00 \%$ & $20.00 \%$ & $46.67 \%$ \\
\hline Female & $11.11 \%$ & $6.67 \%$ & $0.00 \%$ & $51.11 \%$ & $31.11 \%$ \\
\hline Total & $11.67 \%$ & $10.00 \%$ & $0.00 \%$ & $43.33 \%$ & $35.00 \%$ \\
\hline
\end{tabular}

(Study, 2020)

On the above table, it is found that $21.67 \%$ of the total students feel it is unimportant spending less than income. $78.33 \%$ of the students feel it is important for spending less than income. In comparison between male and female, female respondents feel more important to financial records. Out of them, male students are $66.67 \%$ and female students are $82.22 \%$ respectively spending less than income. 
Students planning and implementing regular investment program

Planning and implementing a regular investment program

\begin{tabular}{|l|l|l|l|l|l|}
\hline Gender & A-Very unimportant & B-Unimportant & C-Not sure & D-Important & E-Very important \\
\hline Male & $0.00 \%$ & $6.67 \%$ & $13.33 \%$ & $53.33 \%$ & $26.67 \%$ \\
\hline Female & $6.67 \%$ & $2.22 \%$ & $13.33 \%$ & $40.00 \%$ & $37.78 \%$ \\
\hline Total & $5.00 \%$ & $3.33 \%$ & $13.33 \%$ & $43.33 \%$ & $35.00 \%$ \\
\hline
\end{tabular}

(Study, 2020)

On the above table, it is found that $8.34 \%$ of the total students feel it is unimportant planning and implementing regular investment program whilst $13.33 \%$ of total students feel it is not sure. $78.33 \%$ of the students feel it is an important planning and implementing a regular investment program. In comparison between males and females, male respondents feel more important to financial records. Out of them, male students are $80 \%$ and female students are $77.78 \%$ planning and implementing.

\section{Personal financial management practices}

Students setting aside money each month for savings

Students setting aside money each month for savings

\begin{tabular}{|l|l|l|l|l|l|}
\hline Gender & A-Very unimportant & B-Unimportant & C-Not sure & D-Important & E-Very important \\
\hline Male & $0.00 \%$ & $20.00 \%$ & $6.67 \%$ & $20.00 \%$ & $53.33 \%$ \\
\hline Female & $22.22 \%$ & $28.89 \%$ & $22.22 \%$ & $11.11 \%$ & $15.56 \%$ \\
\hline Total & $16.67 \%$ & $26.67 \%$ & $18.33 \%$ & $13.33 \%$ & $25.00 \%$ \\
\hline
\end{tabular}

(Study, 2020)

Table shows that 38 percent of the students think it is important to set aside money each month for saving. 43.34 percent of the total student think that it is not important to set aside money each month for saving. Remaining 18.33 percent of the students are not sure about setting aside money each month for savings. 
Students set aside money for future needs/wants

Students set aside money for future needs/wants

\begin{tabular}{|l|l|l|l|l|l|}
\hline Gender & A-Very unimportant & B-Unimportant & C-Not sure & D-Important & E-Very important \\
\hline Male & $0.00 \%$ & $20.00 \%$ & $6.67 \%$ & $33.33 \%$ & $20.00 \%$ \\
\hline Female & $15.56 \%$ & $17.78 \%$ & $8.89 \%$ & $28.89 \%$ & $35.56 \%$ \\
\hline Total & $11.67 \%$ & $18.33 \%$ & $8.33 \%$ & $30.00 \%$ & $31.67 \%$ \\
\hline
\end{tabular}

(Study, 2020)

Table shows that 61.67 percent of the students think it is important to set aside money for future needs/wants. 30 percent of the total student think that it is not important to set aside money for future needs/wants. Remaining 8.33 percent of the students are not sure about money for future needs/wants.

Compare prices when shopping for major expenses

Compare prices when shopping for major expenses

\begin{tabular}{|l|l|l|l|l|l|}
\hline Gender & A-Very unimportant & B-Unimportant & C-Not sure & D-Important & E-Very important \\
\hline Male & $0.00 \%$ & $26.67 \%$ & $6.67 \%$ & $20.00 \%$ & $46.67 \%$ \\
\hline Female & $22.22 \%$ & $22.22 \%$ & $15.56 \%$ & $0.00 \%$ & $40.00 \%$ \\
\hline Total & $16.67 \%$ & $23.33 \%$ & $13.33 \%$ & $5.00 \%$ & $41.67 \%$ \\
\hline
\end{tabular}

(Study, 2020)

Table shows that 46.67 percent of the students think it is important to compare prices when shopping for major expenses. 40 percent of the total student think that it is not important to compare prices when shopping for major expenses. Remaining 13.33 percent of the students are not sure about comparing prices when shopping for major expenses.

Use a spending plan or budget

Use a spending plan or budget

\begin{tabular}{|l|l|l|l|l|l|}
\hline Gender & A-Very unimportant & B-Unimportant & C-Not sure & D-Important & E-Very important \\
\hline Male & $20.00 \%$ & $13.33 \%$ & $20.00 \%$ & $26.67 \%$ & $20.00 \%$ \\
\hline Female & $13.33 \%$ & $15.56 \%$ & $20.00 \%$ & $15.56 \%$ & $35.56 \%$ \\
\hline Total & $15.00 \%$ & $15.00 \%$ & $20.00 \%$ & $18.33 \%$ & $31.67 \%$ \\
\hline
\end{tabular}


Table shows that 50 percent of the students think it is important to use a spending plan or budget. 30 percent of the total student think that it is not important to use a spending plan or budget. Remaining 20 percent of the students are not sure about using a spending plan or budget.

Keep track of my expenditure and income

Keep track of my expenditure and income

\begin{tabular}{|l|l|l|l|l|l|}
\hline Gender & A-Very unimportant & B-Unimportant & C-Not sure & D-Important & E-Very important \\
\hline Male & $20.00 \%$ & $6.67 \%$ & $13.33 \%$ & $20.00 \%$ & $40.00 \%$ \\
\hline Female & $22.22 \%$ & $8.89 \%$ & $2.22 \%$ & $8.89 \%$ & $57.78 \%$ \\
\hline Total & $21.67 \%$ & $8.33 \%$ & $5.00 \%$ & $11.67 \%$ & $53.33 \%$ \\
\hline
\end{tabular}

(Study, 2020)

Table shows that 65 percent of the students think it is important to Keep track of my expenditure and income. 30 percent of the total student think that it is not important to Keep track of my expenditure and income. Remaining 5 percent of the students are not sure about Keeping track of my expenditure and income.

The impact of students' financial knowledge on their personal finance decisions

Safest place to keep money

\begin{tabular}{|l|c|c|c|c|}
\hline \multirow{2}{*}{ Gender } & Correct & & Incorrect & \\
\cline { 2 - 5 } & No & Percentage & No & Percentage \\
\hline Male & 10 & $66.67 \%$ & 5 & $33.33 \%$ \\
\hline Female & 19 & $42.22 \%$ & 26 & $57.78 \%$ \\
\hline Total & 29 & $48.33 \%$ & 31 & $51.67 \%$ \\
\hline
\end{tabular}

(Study, 2020)

It is very important to decide to keep money as safe. In this test, 48.33 percent give correct decision and 51.67 percent give incorrect decision. 
Benefit Level for emergencies

\begin{tabular}{|l|c|c|c|c|}
\hline \multirow{2}{*}{ Gender } & Correct & & Incorrect & \\
\cline { 2 - 5 } & No & Percentage & No & Percentage \\
\hline Male & 2 & $13.33 \%$ & 13 & $86.67 \%$ \\
\hline Female & 2 & $4.44 \%$ & 43 & $95.56 \%$ \\
\hline Total & 4 & $6.67 \%$ & 56 & $93.33 \%$ \\
\hline
\end{tabular}

(Study, 2020)

People put money aside to take care of unexpected expenses. Students are asked about the least important options to put money aside. In this test, only 6.67 percent of students give the correct answer, and the remaining 93.33 percent of students give an incorrect answer.

Ways to improve financial health

\begin{tabular}{|l|c|c|c|c|}
\hline \multirow{2}{*}{ Gender } & Correct & & Incorrect & \\
\cline { 2 - 5 } & No & percentage & No & Percentage \\
\hline Male & 13 & $86.67 \%$ & 2 & $13.33 \%$ \\
\hline Female & 36 & $80.00 \%$ & 9 & $20.00 \%$ \\
\hline Total & 49 & $81.67 \%$ & 11 & $18.33 \%$ \\
\hline
\end{tabular}

(Study, 2020)

Students are asked about ways to improve financial health with five options. Among them, 81.67 percent of students give the correct answer, and the remaining 18.33 percent give an incorrect answer. We find that 45.56 percent is the average mean percent of the correct answer of students' financial knowledge on their personal financial decisions where students want to improve their financial knowledge. Students asked where they intend to learn or increase their financial knowledge. The results show that few of the students like to learn from the parents, books, media, jobs, and friends as part of their academic training. The results further show that only 15 percent of the students agree to learn from their campus. These findings can be attributed to the fact that most parents are busy and hence do not create the opportunity for their wards to discuss financial issues with them. Also, 20 and 26.67 of students prefer to learn from life experience and financial institutions respectively. 
Where students expect to learn financial knowledge

\begin{tabular}{|l|c|c|r|r|r|}
\hline \multicolumn{1}{|c|}{ Sources } & Male & Female & Male \% & Female $\%$ & \multicolumn{1}{c|}{ Total } \\
\hline Parents & 2 & 4 & $13.33 \%$ & $8.89 \%$ & $10.00 \%$ \\
\hline Friends & 1 & 2 & $6.67 \%$ & $4.44 \%$ & $5.00 \%$ \\
\hline School & 3 & 6 & $20.00 \%$ & $13.33 \%$ & $15.00 \%$ \\
\hline Books & & 3 & $0.00 \%$ & $6.67 \%$ & $5.00 \%$ \\
\hline Media & 1 & 1 & $6.67 \%$ & $2.22 \%$ & $3.33 \%$ \\
\hline Job & 1 & 2 & $6.67 \%$ & $4.44 \%$ & $5.00 \%$ \\
\hline Life experience & 3 & 9 & $20.00 \%$ & $20.00 \%$ & $20.00 \%$ \\
\hline Financial institutions & 2 & 14 & $13.33 \%$ & $31.11 \%$ & $26.67 \%$ \\
\hline Others & 2 & 4 & $13.33 \%$ & $8.89 \%$ & $10.00 \%$ \\
\hline Total & 15 & 45 & $100.00 \%$ & $100.00 \%$ & $100.00 \%$ \\
\hline
\end{tabular}

(Study, 2020)

\section{Conclusion and suggestion}

\section{Conclusion}

The study reveals that students' knowledge influences his or her opinions and decisions on personal financial behaviors. Majority of the respondents were female students. They were 75 percent out of 60 students. The data showed that $78.33 \%$ of the students lived in the capital town whilst $21.67 \%$ of the students were not. Male students found to be better in personal financial literacy than female students. The observation of parents' education shows that the majority of them didn't not have higher education. Student didn't know how personal budget helps them. In comparison to Chen and Volpe (1998) benchmark of financial literacy, the percentage correct scores are regrouped into three categories: over $80 \%$ (Highest), $60-79 \%$ (Medium) and below $60 \%$ (Low) to make an informed decision on the student's level of financial literacy. It is concluded that students had poor knowledge of personal financial planning. The overall students' performance was $49.84 \%$ which is below the benchmark of Chen, Volpe, and Pavlicko (1998).

\section{Suggestion}

There should be a personal financial literacy program. The priority should be given to female students. Senior aged and middle people should be educated by various financial literacy programs so that they could educate their children family. The findings from this study indicated some doubts about the curriculum used in bachelor level students with respect to financial literacy it is because financial literacy level of students in bachelor level is below average level. The government is 
suggested to revise the course to include a basic financial literacy course. The time is due for stakeholders in the educational system of the country to introduce more and elaborated personal finance courses in the academic curriculum to expose the students to the basic financial concepts which would enable them to improve their financial decision making later in life. Also, since most of the students want to learn through the schools, on the job training, and financial institutions, it is recommended that the students are given the chance to undertake internship courses with the financial institutions to build their financial knowledge capacity. Students should be aware of budgeting and financial planning. They shout to get knowledge about saving and investment chains. Financial literacy programs even in commerce students need to be launched to make them aware. School and college should take them initiation it is because the education system to literate students financially is lacking. The bank and financial institutions are operating financial literacy programs. Central bank of Nepal has issued a circular to allocate some budget to financial literacy. Therefore, banks and financial institutions should initiate such programs from the school and college level to the community and government level. The students are the future and foundation for a civilization of people. Therefore, it is very important to make students capable of taking an appropriate financial decision. There is a need for financial literacy training among students. This should focus on content areas where they lack financial literacy, in order to ensure that students experience financial well-being during the adult years. It is recommended that curriculum should be developed that include internship in the financial institutions.

\section{References}

Abdullah, S., Mohammed, N.H., Salleh, S.M., Rashid, K.M., Kamal, S.S.S.M.K. (2017). F in ancial Literacy among UiTM's Students. Journal of Applied Environmental and Biological Sciences. 7(5S)31-36.

Badal, B.P. (2019). Tourism: Visit Nepal 2020, Research Nepal Journal of development Studies, 2(2), PP. $12-30$.

Chen, H. and Volpe, R.P. (1998). An analysis of personal financial literacy among college students. Financial Services Review, Vol. 7, pp. 107-28.

Huston, S.J., (2010). The American Council on Consumer Interests. The Journal of Consumer Affairs, Vol. 44, No. 2.

Ilias, Seitanidis \& Helen, Tsakiridou. (2019). Financial Literacy of Graduate High School Students. American Journal of Educational Research, Vol. 7, No. 3, 232-236. 
Mahdzan, N.S., Tabiani, S. (2013). The Impact of Financial Literacy on Individual Saving: An Exploratory Study in the Malaysian Context. Transformations in Business \& Economics, Vol. 12, No 1 (28), pp.41- 55.

NRB, (2020). Financial Literacy Framework. Retrieved from https://www.nrb.org.np/.

OECD. (2017). G20/OECD INFE Report on Adult Financial Literacy in G20 Countries.

Peng, T., Bartholomae, S., Fox, J., and Cravener, G. (2007). The impact of finance education delivered in high school and college courses. Financial Counseling and Planning, 17(2), 27 45.27 .

Sarigul \& Hasmet. (2014). A Survey of Financial Literacy Among University Students. The Journal of Accounting and Finance.

Servon, Lisa J., Kaestner, Robert (2008). Consumer financial literacy and the impact of online banking on the financial behavior of lower-income bank customers. Journal of Consumer Affairs.

Swamy, M.B. \& Priya, R. (2017). The Measurement Levels of Financial Literacy among Postgraduate Management Students: An Empirical Study in Andhra Pradesh State Journal of Business and Management. 19(6)

Swiecka, B., Yesilda, E., Ozen E., \& Simon Grima, S. (2020). Financial Literacy: The Case of Poland. Retrieved from https://www.mdpi.com/journal/sustainability.

Thapa, B.S. \& Nepal, S.R. (2015). Financial Literacy in Nepal: A Survey Analysis from College Students. NRB Economic Review.

Walt, F., Fouche., Jaco (2017). Financial Literacy of Undergraduate Students: A Case Study of a Pubic University in South Africa. International journal of economics and finance studies, $9(2)$ 